\title{
Application of image analysis software to the morphometrics of Posidonia oceanica (L.) Delile and Cymodocea nodosa (Ucria) Ascherson
}

\author{
Sante F. Rende ${ }^{1}$, Mascha Stroobant ${ }^{2}$, \\ Ángelo Santana del Pino ${ }^{3}$ and Milena Polifrone,** \\ ${ }^{1}$ ISPRA, Institute for Environmental Protection and \\ Research, via Vitaliano Brancati, 48-00144 Rome, Italy \\ ${ }^{2}$ Departamento de Biología, Universidad de Las Palmas de \\ Gran Canaria, Campus Universitario de Tafira, 35017 Las \\ Palmas de Gran Canaria, Islas Canarias, Spain \\ ${ }^{3}$ Departamento de Matemáticas, Universidad de Las \\ Palmas de Gran Canaria, Campus Universitario de Tafira, \\ 35017 Las Palmas de Gran Canaria, Islas Canarias, Spain \\ ${ }^{4}$ Departamento de Investigación, Desarrollo e Innovación, \\ Seaweed Canarias S.L., C/Herraje 63, Pol. Ind. Arinaga, \\ 35118 Agüimes, Las Palmas, Islas Canarias, Spain, \\ e-mail: milpol@inwind.it \\ * Corresponding author
}

\begin{abstract}
Leaf biometrics are important parameters of seagrasses measured in coastal marine environment-monitoring programs. This study tested the application of several image analysis software packages to the biometry of Posidonia oceanica and Cymodocea nodosa leaves as an alternative to the commonly used manual technique. The biometrics of leaves and epiphytes measured using Image-Pro Plus image analysis software were significantly different from measures made with the manual technique; this was a reflection of the precision of the digital measurements related to the application of "best fit" measures to the shape of the leaves. Among the advantages of the digital method, we found enhanced precision and, presumably, higher accuracy in measurement, faster time of execution, availability of a wide range of free software for image analysis, the permanence of a photographic record, the ability to create data bases to compare new samples with older ones, and the possibility of analysing different morphometric variables on the same sample after a long period of time.
\end{abstract}

Keywords: Cymodocea nodosa; image analysis; morphometrics; Posidonia oceanica; seagrasses.

The ecological importance of seagrass meadows is recognized worldwide due to their high productivity, their stabilising effects on the shoreline, provision of food and shelter for many organisms and their function as nursery areas for commercial fish species (Larkum et al. 1989, Duarte and Cebrian 1996, Costanza et al. 1997). Recent studies on the response of Posidonia oceanica (L.) Delile to different stress conditions confirmed its high value as bio-indicator of environmental disturbance (Pergent et al. 1995, Duarte and Chiscano 1999, Ferrat et al. 2003). For example, $P$. oceanica was used for bio-monitoring the marine environment (Boudouresque et al. 2000) to determine the progression of anthropogenic impact on biocoenotic structure.

The main biological parameters measured in seagrass meadow monitoring usually include shoot density, aboveand below-ground biomasses, lengths, widths and numbers of leaves, leaf area index (LAI) and coefficient A (percentage of leaves having lost their apices) (Pergent-Martini et al. 2005). One method for establishing plant productivity depends on the area of green plant material available for photosynthesis; hence, the LAI is a useful index for estimating the potential productivity of vegetation stands (Hillman et al. 1989). LAI also provides a useful measure of the surface area available for epiphytic organisms, giving an estimate of the potential complexity and richness of the habitat (Hillman et al. 1989).

To date, measurements of seagrass shoots and leaves have been done by hand, following standard techniques for phenological studies, which consider blade length and width among other parameters. Epiphytes on seagrass leaves have been studied classically with a stereomicroscope equipped with a micrometric reticule to estimate the coverage of single species or groups of species in terms of leaf area covered by the orthogonal projection of the epiphyte on the leaf (Boudouresque 1971) or using other demographic approaches that allow estimation of the progression of epiphyte biomass with leaf age (Cebrián et al. 1999).

Increasing use of digital image analysis software for morphometric measurements on different organisms is a methodological revolution in various scientific fields (Adams et al. 2002), and in this work, we propose its application to the study of seagrasses. To test the potential of digital image analysis methods for biometric measurement of seagrass leaves and their epiphytes, we compared manual and digital measurements made on two ecologically important species, P. oceanica and Cymodocea nodosa (Ucria) Ascherson.

Using the manual method, the mean length of the sheath in adult leaves of $P$. oceanica was $2.6 \pm 1 \mathrm{~cm}$, while the mean length and width of adult leaves were $18.6 \pm 10.2 \mathrm{~cm}$ and $0.8 \pm 0.07 \mathrm{~cm}$, respectively; intermediate leaves were on average $20.9 \pm 12.0 \mathrm{~cm}$ long and $0.7 \pm 0.06 \mathrm{~cm}$ wide, while young leaves were $3.2 \pm 1.5$ $\mathrm{cm}$ long and $0.7 \pm 0.04 \mathrm{~cm}$ wide (Table 1). In general, leaf 
Table 1 Biometrics of leaves of Posidonia oceanica and Cymodocea nodosa.

\begin{tabular}{|c|c|c|c|c|c|}
\hline & $\begin{array}{l}\text { Mean } \pm \sigma \text { of manual measure } \\
\text { (minimum-maximum) }\end{array}$ & $\begin{array}{l}\text { ANOVA } \\
\text { p-value }\end{array}$ & $\begin{array}{l}\Delta \text { Mean } \\
\text { ImageJ }\end{array}$ & $\begin{array}{l}\Delta \text { Mean } \\
\text { Image-Pro Plus }\end{array}$ & $\begin{array}{l}\Delta \text { Mean } \\
\text { tpsDig2 }\end{array}$ \\
\hline \multicolumn{6}{|l|}{ Posidonia oceanica } \\
\hline \multicolumn{6}{|l|}{ Length (cm) } \\
\hline Sheath & $\begin{array}{l}2.56 \pm 1.0 \\
(0.4-5.5)\end{array}$ & $<0.001$ & -0.0342 & $0.0895 * * *$ & 0.0031 \\
\hline Adult leaves & $\begin{array}{l}18.57 \pm 10.2 \\
(3.2-43.0)\end{array}$ & $<0.001$ & 0.1018 & $0.5082 * * *$ & 0.1317 \\
\hline Intermediate leaves & $\begin{array}{l}20.92 \pm 12.0 \\
(5.0-48.5)\end{array}$ & $<0.001$ & 0.0577 & $0.5283^{* * *} *$ & -0.0242 \\
\hline Young leaves & $\begin{array}{l}3.17 \pm 1.5 \\
(1.2-5.7)\end{array}$ & 0.008 & 0.0350 & $0.2090 * *$ & 0.0290 \\
\hline \multicolumn{6}{|l|}{ Width $(\mathrm{cm})$} \\
\hline Adult leaves & $\begin{array}{l}0.81 \pm 0.07 \\
(0.7-1.0)\end{array}$ & 0.619 & -0.0105 & -0.0096 & -0.0023 \\
\hline Intermediate leaves & $\begin{array}{l}0.74 \pm 0.06 \\
(0.6-0.9)\end{array}$ & 0.002 & 0.0089 & $0.0341 *$ & -0.0077 \\
\hline Young leaves & $\begin{array}{l}0.68 \pm 0.04 \\
(0.6-0.7)\end{array}$ & 0.530 & 0.0283 & 0.0443 & 0.0089 \\
\hline \multicolumn{6}{|l|}{ Surface area $\left(\mathrm{cm}^{2}\right)$} \\
\hline Adult leaves & $\begin{array}{l}15.18 \pm 8.9 \\
(2.2-38.2)\end{array}$ & 0.626 & -0.0895 & 0.1639 & 0.0722 \\
\hline Intermediate leaves & $\begin{array}{l}15.86 \pm 10.0 \\
(3.2-42.3)\end{array}$ & $<0.001$ & 0.2203 & $0.8888 * * *$ & 0.0403 \\
\hline Young leaves & $\begin{array}{l}1.97 \pm 0.89 \\
(0.7-3.3)\end{array}$ & 0.526 & 0.0970 & 0.1937 & 0.0471 \\
\hline \multicolumn{6}{|l|}{ Cymodocea nodosa } \\
\hline Sheath & $\begin{array}{l}5.71 \pm 3.7 \\
(1.2-13.6)\end{array}$ & 0.175 & 0.0311 & 0.1719 & -0.1139 \\
\hline Adult leaves & $\begin{array}{l}20.69 \pm 12.1 \\
(1.7-46.5)\end{array}$ & 0.910 & -0.0253 & -0.2897 & -0.1100 \\
\hline Young leaves & $\begin{array}{l}13.63 \pm 6.8 \\
(0.8-34.7)\end{array}$ & 0.312 & -0.0912 & 0.1628 & 0.3932 \\
\hline \multicolumn{6}{|l|}{ Width $(\mathrm{cm})$} \\
\hline Adult leaves & $\begin{array}{l}0.27 \pm 0.06 \\
(0.2-0.4)\end{array}$ & 0.826 & 0.033 & 0.0041 & 0.0016 \\
\hline Young leaves & $\begin{array}{l}0.27 \pm 0.08 \\
(0.2-0.4)\end{array}$ & $<0.001$ & 0.0174 & $0.0305 * * *$ & 0.0136 \\
\hline \multicolumn{6}{|l|}{ Surface area $\left(\mathrm{cm}^{2}\right)$} \\
\hline Adult leaves & $\begin{array}{l}5.57 \pm 3.2 \\
(0.3-13.9)\end{array}$ & 0.986 & -0.0268 & -0.0504 & -0.0434 \\
\hline Young leaves & $\begin{array}{l}3.53 \pm 1.7 \\
(0.2-8.7)\end{array}$ & $<0.001$ & 0.2640 & $0.5715^{* * *}$ & 0.2702 \\
\hline
\end{tabular}

Two populations of each species were analysed using 15 shoots with 95 leaves of $P$. oceanica from Diamante (Calabria, Italy) and from Santa Marinella (Lazio, Italy) and 15 shoots with 40 leaves of $C$. nodosa from Risco Verde (Canary Islands, Spain) and from Santa Marinella (Lazio, Italy). The leaves of each shoot of P. oceanica were separated into three groups as described by Giraud (1977): adult, intermediate and young leaves. For $C$. nodosa, we differentiated only between adult and young leaves. Each leaf was manually measured and then laid on millimeter paper, photographed with a fixed digital camera (Nikon, Tokyo, Japan D70 with 6.0Mp) and analysed using three software packages for image analysis: ImageJ v. 1.39d (Rasband, 2007), tpsDig2 (Rohlf, 2004) and Image-Pro Plus v. 4.5 (Media Cybernetics, Silver Spring, MD, USA). All measurements were made after calibrating the software with millimeter grid paper because the software tools base their algorithms on a pixel comparison within a defined scale inside each image. Observational bias and error were greatly reduced by using only one person to analyse digital photographs. Manual areas and tpsDig2 areas were both calculated on the basis of length and width of leaves as this software does not have a threshold function to calculate areas. Analysis of variance with repeated measures was applied to all variables for the same leaf or sheath, and mean values were compared across the four procedures using the statistical program $\mathrm{R}$ ( $\mathrm{R}$ Development Core Team, 2009). Mean values (cm), standard deviation (cm), range of maximum and minimum values (cm) and ANOVA p-values are reported. Tukey's simultaneous confidence intervals (95\% family-wise confidence level) were calculated to obtain estimates of differences between digital and manual measurements. When significant differences were observed, multiple comparisons of means by Tukey contrasts were carried out to determine which measure differed significantly from the manual measurement (level of significance $* \mathrm{p}<0.05, * * \mathrm{p}<0.01, * * * \mathrm{p}<0.001)$. 
measurements calculated by digital image analysis methods did not differ significantly from manual measurements in Tukey multiple comparisons of means. Sheath and leaf lengths measured with ImageJ and with tpsDig2 did not differ from the manual technique; measurements made using Image-Pro Plus were significantly different from all other measurements $(p<0.001)$. A significant difference in measurements of widths of leaves was found only for intermediate leaves measured with Image-Pro Plus $(\mathrm{p}<0.05)$. However, despite the statistical significance, the greatest differences in measurements were only $0.528 \mathrm{~cm}$ in length and $0.03 \mathrm{~cm}$ in width of intermediate leaves (Table 1), which may be considered irrelevant at a practical level when considering the ecological implications of these measurements. Moreover, the $0.03 \mathrm{~cm}$ difference observed in the widths of intermediate leaves is below the margin of error for manual measurements $(0.05 \mathrm{~cm})$. We must also consider leaf shape as a factor that influences measurements. Most $P$. oceanica leaves have a curved profile, and hence, leaf length is most precisely estimated by the algorithm in Image-Pro Plus, which automatically generates measurements based on an arc best fitted to several points on the image created by a tool called "best fit arc". This kind of measure reduces the cumulative error generated in measurements made manually or with the other software in which curved leaves are measured as the sum of several linear segments. The morphology of leaves also explains the different patterns for $C$. nodosa, for which there was no significant difference in leaf length between manual and Image-Pro Plus measurements. Indeed, $C$. nodosa leaves are almost completely linear, which reduces the potential for measurement error and eliminates possible dissimilarities among softwares.

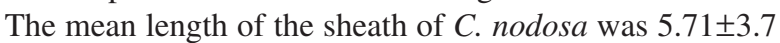
$\mathrm{cm}$, the mean length and width of the adult leaves were $20.69 \pm 12.1 \mathrm{~cm}$ and $0.27 \pm 0.06 \mathrm{~cm}$, respectively, while young leaves were $13.63 \pm 6.8 \mathrm{~cm}$ long and $0.27 \pm 0.08 \mathrm{~cm}$ wide (Table 1). A significant difference of $0.03 \mathrm{~cm}(\mathrm{p}<0.001)$ was observed in the measurement of the widths of young leaves. In this case, as in P. oceanica, the difference in leaf size may be considered ecologically negligible.

The image analysis method proposed here for the study of epibionts on seagrass leaves can be used to establish the number of epibionts, area covered and to differentiate their type (encrusting or erect algae, bryozoans, hydrozoans and foraminifera). Only encrusting algae were recorded in this study, and we did not differentiate animal taxa because of the small number of animal epiphytes on the leaves. We observed 29 epiphytes on the leaves of $P$. oceanica; 18 of them were encrusting macroalgae (mean surface area of $0.16 \pm 0.28 \mathrm{~cm}^{2}$ ), and 11 were animals (mean surface of $0.49 \pm 0.31 \mathrm{~cm}^{2}$; Table 2). The

Table 2 Surface areas of epibionts on leaves of Posidonia oceanica and Cymodocea nodosa.

\begin{tabular}{|c|c|c|c|c|}
\hline \multirow[t]{2}{*}{ Method of measurements } & \multicolumn{2}{|c|}{ Posidonia oceanica } & \multicolumn{2}{|l|}{ Cymodocea nodosa } \\
\hline & Macroalgae & Animals & Macroalgae & Animals \\
\hline \multicolumn{5}{|l|}{ Micrometric reticule } \\
\hline Mean $\pm \sigma$ of epibiont area & $0.160 \pm 0.28$ & $0.488 \pm 0.31 * * *$ & $0.022 \pm 0.02$ & $0.034 \pm 0.01 * * *$ \\
\hline (minimum-maximum) & $(0.005-0.957)$ & $(0.048-0.973)$ & $(0.001-0.060)$ & $(0.013-0.049)$ \\
\hline Mean $\pm \sigma \%$ of leaf area covered & $47.95 \pm 35.31 \%$ & $76.81 \pm 13.82 \% * * *$ & $39.09 \pm 23.74 \% * * *$ & $50.60 \pm 7.63 \% * * *$ \\
\hline \multicolumn{5}{|l|}{ ANOVA p-value } \\
\hline Mean epibiont area & 0.494 & $<0.001$ & 0.200 & $<0.001$ \\
\hline Mean $\%$ of leaf area covered & 0.617 & $<0.001$ & $<0.001$ & $<0.001$ \\
\hline \multicolumn{5}{|l|}{ Visilog } \\
\hline$\Delta$ Mean epibiont area & -0.0374 & -0.0829 & -0.0004 & -0.0094 \\
\hline$\Delta$ Mean $\%$ of leaf area covered & -11.2845 & -12.9830 & -5.8363 & -13.8999 \\
\hline \multicolumn{5}{|l|}{ ImageJ } \\
\hline$\Delta$ Mean epibiont area & -0.0322 & 0.0837 & -0.0032 & -0.0096 \\
\hline$\Delta$ Mean $\%$ of leaf area covered & -9.6667 & -13.1571 & -5.7498 & -14.2259 \\
\hline \multicolumn{5}{|l|}{ Image Tool } \\
\hline$\Delta$ Mean epibiont area & -0.0329 & -0.0833 & -0.0031 & -0.0095 \\
\hline$\Delta$ Mean $\%$ of leaf area covered & -9.8588 & -13.0922 & -5.5475 & -14.0207 \\
\hline \multicolumn{5}{|l|}{ Image-Pro Plus } \\
\hline$\Delta$ Mean epibiont area & -0.0231 & $-0.1601 * * *$ & -0.0037 & -0.0099 \\
\hline$\Delta$ Mean $\%$ of leaf area covered & -6.9204 & $-25.1608 * * *$ & -6.7510 & -14.7833 \\
\hline
\end{tabular}

In this procedure, we selected 10 leaves from each seagrass species collected at Santa Marinella (Italy). Images were captured on millimeter gridded paper using an Epson ${ }^{\circledR}$ GT-15000 (Epson America, Inc., USA) Scanner at 1200 dpi; software packages used were Visilog 6.4 Viewer (Rende et al. 2009), ImageJ 1.39v (Rasband, 2007), ImageTool v. 3.0 (UTHSCSA, TX, USA) and Image-Pro Plus v. 4.5, all based on the threshold algorithm (tpsDig2 software was not included because it does not have an algorithm to determine surface area). Sectors of $1 \mathrm{~cm}^{2}$ were randomly chosen on each leaf of P. oceanica, while for C. Nodosa, we used smaller sectors of $9 \mathrm{~mm}^{2}$ to fit the small leaves. Epibionts were sorted only by macrophytes and animals. Analysis of variance with repeated measures was applied for all variables, and mean values were compared for the same leaf with the four procedures using the statistical program R (R Development Core Team, 2009). Mean values ( $\mathrm{cm}^{2}$ ), standard deviation $\left(\mathrm{cm}^{2}\right)$, range of maximum and minimum values $\left(\mathrm{cm}^{2}\right)$, percentage of leaf area covered by epibionts $(\%)$ and ANOVA p-values are reported. Tukey's simultaneous confidence intervals (95\% family-wise confidence level) were calculated out to obtain estimates of differences between measurements obtained using digital image analysis and the classical method. When significant differences were observed, the multiple comparisons of means by Tukey contrasts were carried out to determine which measurement significantly differed from the manual measurement (level of significance $* \mathrm{p}<0.05, * * \mathrm{p}<0.01, * * * \mathrm{p}<0.001)$. 
mean percentage of $P$. oceanica leaf area covered by macroalgae was $47.9 \pm 35.3 \%$, and the percentage covered by animals was $76.8 \pm 13.8 \%$. We found 17 epiphytes on $C$. nodosa leaves; 13 of them were encrusting macroalgae (mean surface area of $0.02 \pm 0.02 \mathrm{~cm}^{2}$ ), and four were animals (mean surface area of $0.03 \pm 0.01 \mathrm{~cm}^{2}$ ). The mean percentage of leaf area covered by macroalgae was $39.1 \pm 23.7 \%$, and the percentage covered by animals was $50.6 \pm 7.6 \%$. We observed the same number of epibionts by image analysis software and manual counting with a micrometric reticule. However, estimates of surface area covered by epibionts were significantly lower using image analysis techniques than those obtained by the classical method (with the exception of macroalgal cover on $P$. oceanica, which was highly variable; Table 2). On the one hand, using the classical method, the researcher has to count the number of quadrats of the reticule occupied by epibionts and apply considerable approximation at the edges of the epibiontic areas. On the other hand, software tools allow exact measurement of the number of pixels occupied by epibionts and convert counts to $\mathrm{cm}^{2}$ by using the metric scale supplied in the image. Nevertheless, results obtained for areas of epibiont cover in this study should be interpreted with caution because of the limited sample size considered.

During this past decade, use of digital image analysis in the field of biology has increased, replacing slow manual measurements with more efficient semi-automated procedures(Macholán 2006, McGuican and Blows 2007). Several researchers have applied photographic or video sampling in the marine environment. Marcom et al. (1998) compared the Braun-Blanquet rating scheme with a digitised cover method to examine the percentage cover of epiphytic non-geniculate coralline algae, observing a major improvement in the effectiveness of the digital method over the classical one. O'Neal et al. (2002) and Sandrini-Neto et al. (2007) described new methods of digital analysis to determinate the foliar consumption on mangroves by herbivores. Ponton (2006) tested the efficiency of geometric morphometrics for the analysis of otolith shape for different fish species. Broad et al. (2010) used baited remote underwater video units to assess the potential impact of shark repulsion devices on the behaviour of chondrichthyan and osteichthyan fishes. Waddington et al. (2010) described a remote still photography system for collection of benthic photo-quadrats.

The present approach to seagrass biometry is a natural consequence of a new tendency towards the use of modern digitised methods in marine research. We compared the results of manual and diverse digital measurements collected from the same samples to set benchmarks for application of the new techniques to morphometrics of seagrasses. Very little difference was observed between the digital and manual measurements, and in practice, they would not be of ecological relevance: manual and digital values diverged by $<0.05 \mathrm{~cm}$ for leaf width and by about $0.5 \mathrm{~cm}$ for leaf length. Differences among the software tools may be explained by the different algorithms they utilise, which lead to varying levels of precision in the results. Image-Pro Plus had the highest precision in measurement, resulting in significantly different values for many of the parameters measured by both manual measurements and results obtained from the other software packages. For this reason, the "best" digital measure will not always be the method that provides values most similar to the manual one because image analysis is likely to be more accurate. From the data obtained, it is evident that differences among manual and digital measurements are ecologically and taxonomically unimportant, independent of the software utilised. Although the selection of software with the maximum degree of automatic measurement (such as "best fit" options) might be an advantage, there are several programs that are freely available and can be applied to this kind of study without concerns about the accuracy of data analysis.

Among the advantages of the digital method over the manual one, together with the accuracy of the measurements, is the efficiency of the technique. Digital image analysis offers a faster execution time as the manual measurements required several hours of practical work, while the digital method may be performed in half an hour or a little more, depending on the sample size. A reduced working time also corresponds to a limited exposure of the researcher to formalin-preserved samples and, hence, the possibility for the scientist to work in an environment with fewer unsafe chemicals.

Although in this study we have considered only a few variables related to the leaves, the method could be applied to many other measures of seagrass meadows, such as epibiont cover, leaf growth and productivity, standing crop and leaf density applied directly in the field.

The permanence of an historical photographic record of the sample offers another important advantage of digital methodology, as a sample is not normally conserved after manual measurements are made. The image analysis method allows a researcher to create a database to compare new samples with older ones or to compare samples from different localities and periods, as well as the possibility of applying new morphometric variables to a sample previously analysed.

\section{Acknowledgements}

We would like to acknowledge the assistance of Adrián AbelardoGonzález and David Trujillo-Castellano during sampling in Canary Islands. We also acknowledge Roberto Cresca, Paolo Zotti, Maria Grazia Zappone and Emanuela Garau of the Sistema Difesa Mare of the Ministero dell'Ambiente e della Tutela del Territorio e del Mare (Roma, Italy).

\section{References}

Adams, D.C., F.J. Rohlf and D.E. Slice. 2002. Geometric morphometrics: ten years of progress following the "revolution". Ital. J. Zool. 71: 5-16.

Boudouresque, C.F. 1971. Méthodes algologiques. Biblioth. Phycol. 9: 1-196.

Boudouresque, C.F., E. Charbonel, A. Meinesz, G. Pergent, C. Pergent-Martini, G. Cadiou, M.C. Bertrandy, P. Foret, P. Ragazzi and V. Rico-Raimondino. 2000. A monitoring network based on the seagrass Posidonia oceanica in the northwestern Mediterranean sea. Biol. Mar. Medit. 7: 328-331.

Broad, A., N. Knott, X. Turon and A.R. Davis. 2010. Effects of a shark repulsion device on rocky reef fishes: no shocking outcomes. Mar. Ecol. Prog. Ser. 408: 295-298. 
Cebrián, J., S. Enríquez, M. Fortes, N. Agawin, J.E. Vermaat and C.M. Duarte. 1999. Epiphyte accrual on Posidonia oceanica (L.) Delile leaves: implications for light absorption. Bot. Mar. 42: 123-128.

Costanza, R., R. d'Arge, R. de Groot, S. Farber, M. Grasso, B. Hannon, K. Limburg, S. Naeem, R. O'Neill, J. Paruelo, G. Raskin, P. Sutton and M. van den Belt. 1997. The value of the world's ecosystem services and natural capital. Nature 387: 253-260.

Duarte, C.M. and J. Cebrian. 1996. The fate of marine autotrophic production. Limnol. Oceanogr. 41: 1758-1766.

Duarte, C.M. and C.L. Chiscano. 1999. Seagrass biomass and production. Aquat. Bot. 65: 159-174.

Ferrat, L., C. Pergent-Martini and M. Romèo. 2003. Assessment of the use of biomarkers in aquatic plants for the evaluation of environmental quality: application to seagrasses. Aquat. Toxicol. 65: 187-204.

Giraud, G. 1977. Essai de classement des herbiers de Posidonia oceanica (L.) Del. Bot. Mar. 20: 487-491.

Hillman, K., D.I. Walker, A.W.D. Larkum and A.J. McComb. 1989. Productivity and nutrient limitation. In: (A.W.D. Larkum, A.J. McComb and S.A. Shepherd, eds.) Aquatic plant studies 2. Biology of seagrasses. A treatise on the biology of seagrasses with special reference to the Australian region. Elsevier, Amsterdam. pp. 635-685.

Larkum, A.W.D., A.J. McComb and S.A. Shepherd. 1989. Aquatic plant studies 2. Biology of seagrasses. A treatise on the biology of seagrasses with special reference to the Australian region. Elsevier, Amsterdam. pp. 841.

Macholán, M. 2006. A geometric morphometric analysis of the shape of the first upper molar in mice of the genus Mus (Muridae, Rodentia). J. Zool. 270: 672-681.

Marcom, N.F., S.A. Ward and W.J. Woelkerling. 1998. Cover estimates of epiphytic coralline algae (Corallinales, Rhodophyta): Braun-Blanquet vs Computer Image Analysis. Cryptogam. Algol. 19: 303-309.

McGuican, K. and M.W. Blows. 2007. The phenotypic and genetic covariance structure of drosphilid wings. Evolution 61: 902-911.
O'Neal, M.E., D.A. Landis and R. Isaacs. 2002. An inexpensive, accurate method for measuring leaf area and defoliation through digital image analysis. J. Econ. Entomol. 95: 1190-1194.

Pergent, G., C. Pergent-Martini and C.F. Boudouresque. 1995. Utilisation de l'herbier à Posidonia oceanica comme indicateur biologique de la qualité du milieu littoral en Mèditerranée: ètat de connaissances. Mèsogèe 54: 3-29.

Pergent-Martini, C., V. Pasqulini, L. Ferrat, G. Pergent and C. Fernández. 2005. Seasonal dynamics of Zostera noltii Hornem. in two Mediterranean lagoons. Hydrobiologia 543: 233-243.

Ponton, D. 2006. Is geometric morphometrics efficient for comparing otolith shape of different fish species? J. Morphol. 267: 750-757.

R Development Core Team. 2009. R: a language and environment for statistical computing. R Foundation for Statistical Computing, Vienna, Austria. ISBN 3-900051-07-0, URL http://www.Rproject.org.

Rasband, W.S. 2007. US ImageJ-rsb. info. nih. gov/ij/(1997-2007).

Rende, F., S. Frangella, M. Polifrone, M. Stroobant, M. Burgassi and F. Cinelli. 2009. Vision 1.0: software sperimentale per la valutazione rapida del ricoprimento macrofitobentonico. Biol. Mar. Mediter. 16: 296-297.

Rohlf, F.J. 2004. TpsDig, digitize landmarks and outlines, Version 2.0. Department of Ecology and Evolution, State University of New York, Stony Brook, New York.

Sandrini-Neto, L., L. Hostin, P. Lana and F. Pellizzari. 2007. Un nuevo método de análisis digital para la determinación de los niveles de consumo foliar. Investig. Mar. 35: 111-116.

Waddington, K.I, B.W. Piek, A.D. Payne, S.L. Grove, E.S. Harvey, G.A. Kendrick, H.F. Taylor and J.J. Meeuwig. 2010. Description of a remote still photography system for the collection of benthic photo-quadrats. Mar Technol. Soc. J. 44: 56-63.

Received 14 March, 2011; accepted 19 January, 2012; online first 5 March, 2012 